\title{
RISK ASSESSMENT METHODOLOGY AT ISLA DEL CARMEN, MEXICO
}

\author{
Mireille Escudero Castilloํㅡㄹ Edgar Mendoza Baldwin ${ }^{1}$ and Rodolfo Silva Casarín
}

Extreme hydro-meteorological phenomena lead annually to serious damage and losses in the coastal zone of Isla del Carmen, on the Gulf of Mexico. The importance of the risk assessment is the possibility of preventing or reducing those harmful effects. In this context, an integrated risk assessment approach is performed based on the source-pathway-receptor concept to assess the flooding risk in the area. The paper analyses the consequences on the dune ecosystem that extends longitudinally along the island; and the effects on the population, infrastructure and natural habitat located next to the beach. The results of the study will be used to define the zones with a higher level of risk and to propose flood risk mitigation measures. Moreover, the study will contribute to the establishment of specific legislation which supports the protection of the coastal dune.

Keywords: flooding risk; hydro-meteorological hazards; risk source-pathway-receptor approach

\section{INTRODUCTION}

Isla del Carmen is part of the morphological lagoon-estuarine system of Terminos lagoon (Figure 1), limited at the Southwest and Northeast by the two mouths of the lagoon. The Carmen natural inlet, at the SW, shows fluxes directed towards the interior or exterior of the lagoon depending on the season of the year and the Puerto Real artificial inlet, at the NE, always presents a predominance of flow directed towards the interior of the lagoon (Marquez 2008).
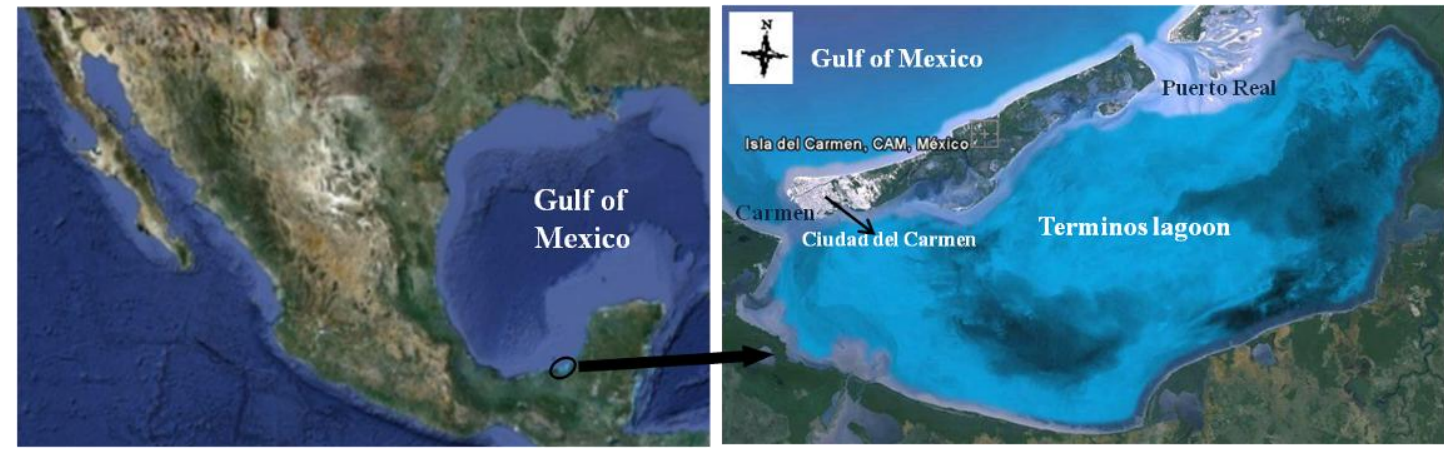

Figure 1. Location of study site.

Along the coastal zone of Isla del Carmen a small dune can be found, three to four meters high, which extends longitudinally along the almost forty kilometers of beach (Figure 2a) protecting the urban areas of Ciudad del Carmen as well as the natural ecosystem of Terminos lagoon. This lagoon is considered a "Protected Natural Area of Flora and Fauna"; an area of mangroves (Figure 2b) with biological relevance (CONABIO 2009), and is a UNESCO world heritage site since 2008. Moreover, the ecological relevance of the site is highlighted as an area of sea turtle spawning.

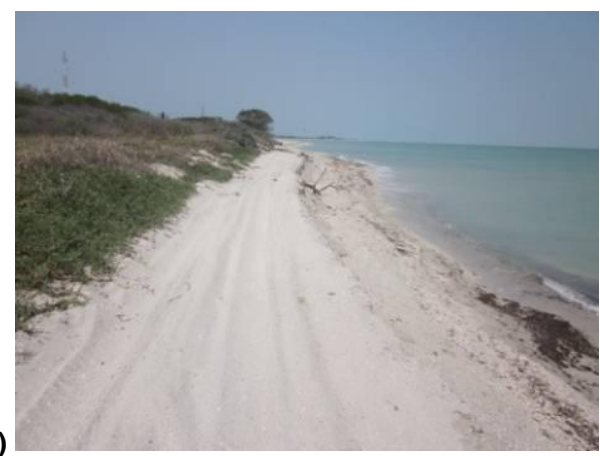

Figure 2. (a) Dune; (b) Mangrove zone.

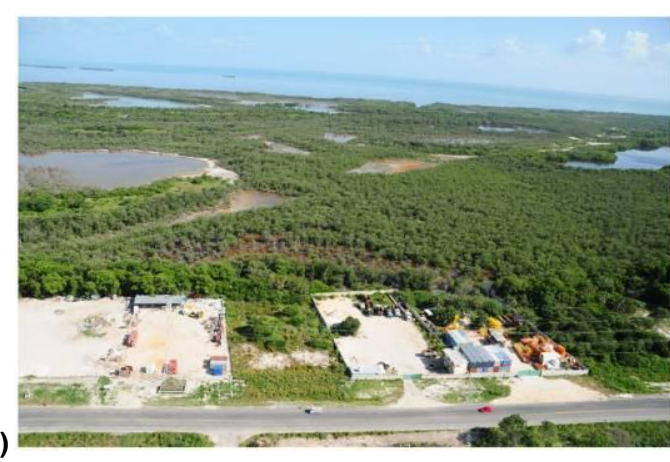

b)

${ }^{1}$ Engineering Institute, National Autonomous University of Mexico, Circuito Escolar s/n, Edificio 5, Mexico City, 04510 , Mexico 
The study area is affected annually by very strong winds of polar origin (known locally as "Nortes"); as well as by extreme events, such as hurricanes, both of which cause erosion problems on the beach and processes of breaching, overtopping and overwash in the dune. All these cause flooding of human settlements and natural habitats next to the beach which is increased by the degradation of the coastal dune due to construction over it and the removal of dune vegetation.

Figure 3a shows different pictures taken during a "Norte" event and Dean Hurricane in Ciudad del Carmen, and figure $3 \mathrm{~b}$ shows several examples of badly designed defense structures along the Isla del Carmen beach.

(a)
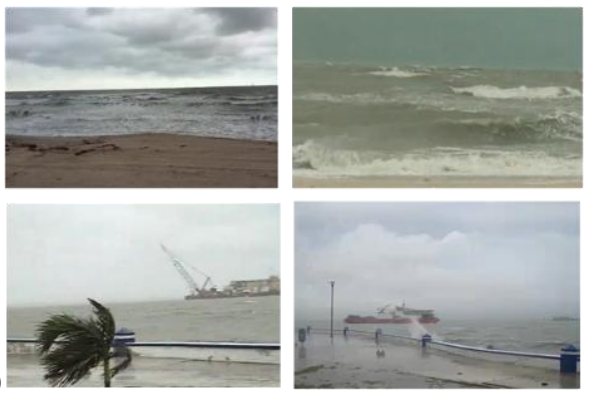

(b)

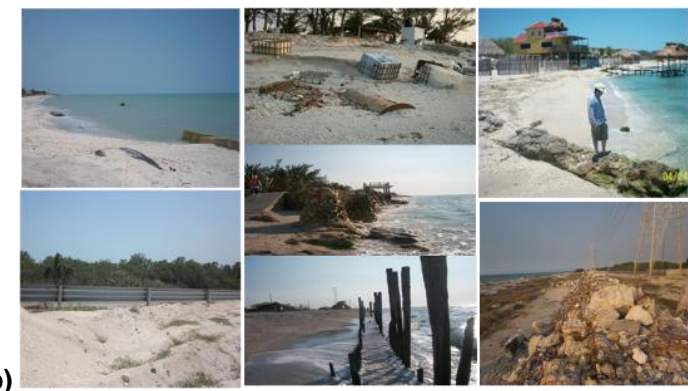

Figure 3. (a) "Norte" event and Dean Hurricane (October 2007).

(b) Badly designed defense structures.

Given the high level of damage already registered and the expectancy of worse climate conditions, it is important to carry out a risk assessment to preserve the existing natural ecosystems in adequate conditions in the zone, and to prevent or reduce the considerable economic and social damage caused every year by these phenomena on the population and tourists of Ciudad del Carmen. However, at the moment there are not sufficient studies which simply analyze and/or assess the hazards in the area. Furthermore, there is no specific legislation to provide support for the protection of the coastal dune.

This paper aims to assess the flooding risk in the coastal zone of Isla del Carmen, by means of the application of the risk source-pathway-receptor approach (Burzel et al. 2010; Jha 2011; Narayan et al. 2011).

\section{METHODOLOGY}

Risk is defined as the combination of probability and consequences (Helm 1996; Gouldby 2005; Burzel et al. 2010), and can be expressed by:

$$
R=P \cdot D
$$

where $\mathrm{P}$ is the probability of occurrence of a harmful event; and $\mathrm{D}$ are the consequences or damages expected on all physical entities exposed to the threat.

The risk definition previously mentioned is integrated into the recent and innovative sourcepathway-receptor concept as risk assessment methodology (Oumerachi et al. 2009), hence this model allows a better representation of physical processes taking place on the propagation and consequences of a particular event of flooding. The definition of each factor is as follows:

- Source of risk: is defined as climatic factors inducing flooding, e.g. tsunamis, storm surges, waves or wind.

- Pathway: describes the main variables and processes controlling the flooding risk on its way from the source to the receptor.

- Receptor: are all physical entities exposed to the threat, such as people, buildings, possessions, property, infrastructure or environment.

The source-pathway-receptor model is applied from two different perspectives (figure 4):

1) The dune is considered as a receptor element: the aim is to analyze the risks (or consequences), of the storm surge, wave and wind hazards (or sources) on the dune ecosystem.

2) The dune is considered as a pathway element: the aim is to analyze the risks (consequences) produced by the storm surge, wave and wind hazards (sources) on the population, infrastructure and 
natural habitat located in the area protected by the dune. In particular, the study is focused on an area of two kilometers inland from the coastline.

- Case 1:

\begin{tabular}{|l|}
\hline Sources \\
\hline - Wind \\
- Wave \\
-Storm surge \\
\hline
\end{tabular}

Pathway
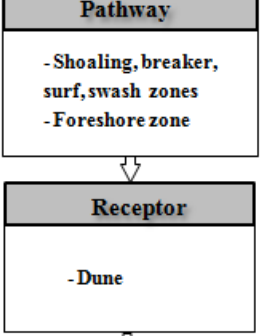

रु

Consequences

-Loss of dune ecosystem
- Case 2:

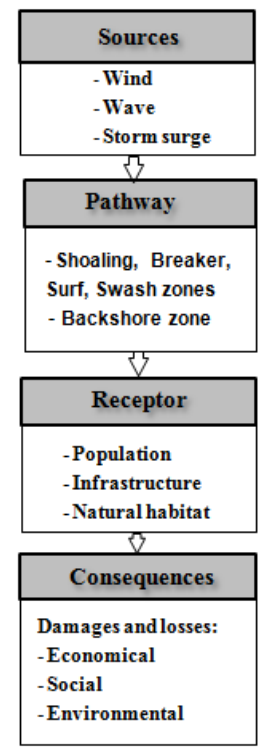

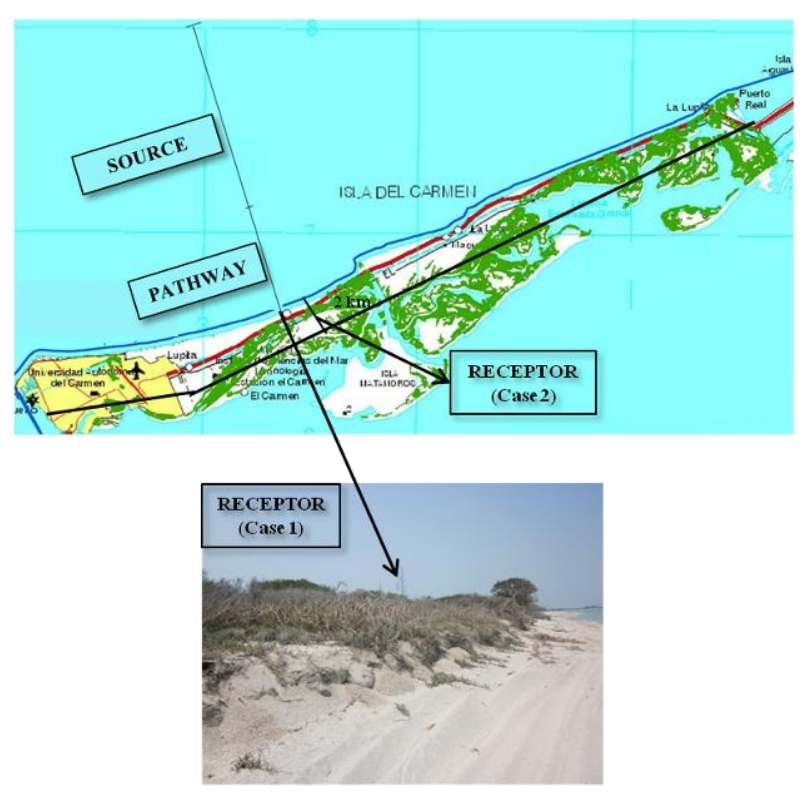

Figure 4. Sketch of the source-pathway-receptor model application at the study site.

The characterization of each model component is as follows:

- Sources: are obtained at 28 meters depth (68 kilometers from coastline) from reanalysis data base, and defined as the combination of monochromatic wave and uniform storm surge associated with a return period of $2,5,10,20,3050,100$ and 250 years.

- Pathway: sources are lineally propagated from 28 to 20 meters depth (57 kilometers from coastline) due to the shallow seabed features in the area, depth from which the Refdif (Kirby and Dalrymple 1994) and XBeach (Roelvink et al. 2010) numerical models are applied, see Figure 5. Refdif model, which solves shoaling and refraction processes, is used to approximate the wave and sea level conditions from 20 to 7 meters depth; XBeach model, which solves overwash, avalanching and breaching processes (among others) is applied from 7 meters depth to the receptor using a more detailed grid to properly simulate the hydrodynamic and morphological processes that occur on the breaker, surf, swash, foreshore and backshore zones of the beach.

- Receptor: the consequences on the receptor are assessed in terms of vulnerability indices for each inundation depth associated with the return periods analyzed.

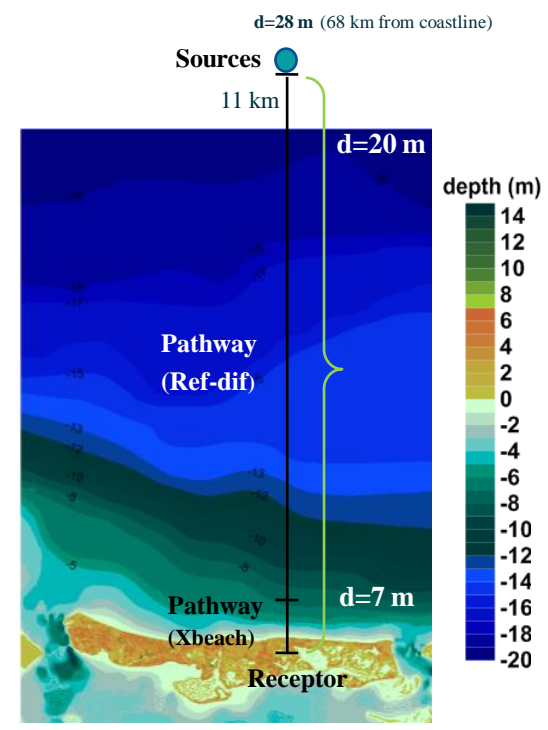

Figure 5. Sketch of the source-pathway-receptor model characterization at the study site. 


\section{RESULTS}

\section{Sources of risk}

The wind and wave database consists of a series of hourly sea states from 1948 to 2010 (62 years) resulting from the application of Hurac and WAM numerical models for extreme and normal conditions, respectively (Monbaliu 2000). The storm conditions in the zone are defined by a significant wave height equal to one meter.
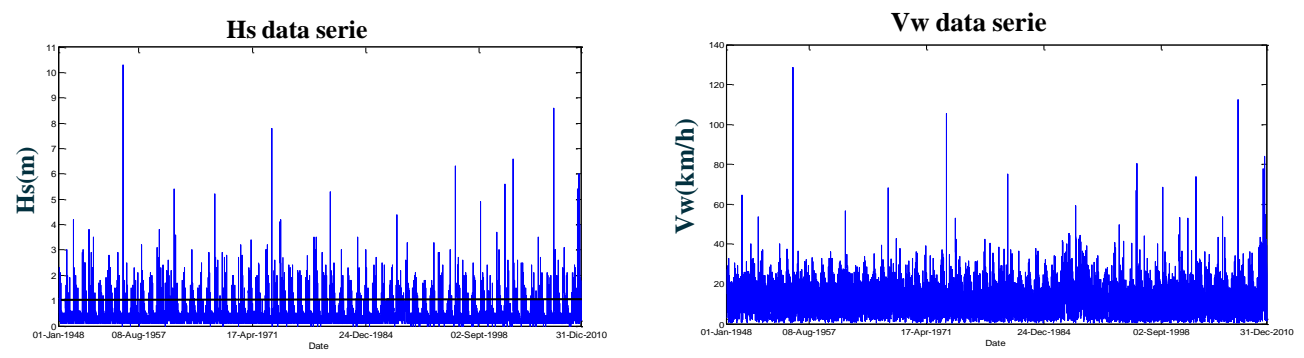

Figure 6. Significant wave height and wind velocity data series.

On the other hand, the storm surge values are obtained from the application of a hydrodynamic model known as MATO (Posada 2007; Durán 2010), in several cells situated 6-8 kilometers from the coastline. The model result is the mean sea level rise as a function of the simulation time under uniform wind forcing, as shown in figure 7a for wind coming from ENE in any of the cells analyzed. The storm surge values associated with a specific wind velocity are obtained by taking into account the model assumption of parabolic relation between them (figure $7 b$ ).

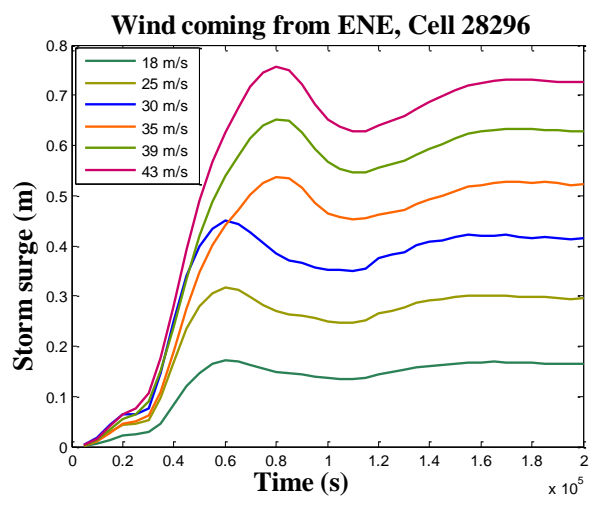

(b)

Wind coming from ENE, Cell 28296

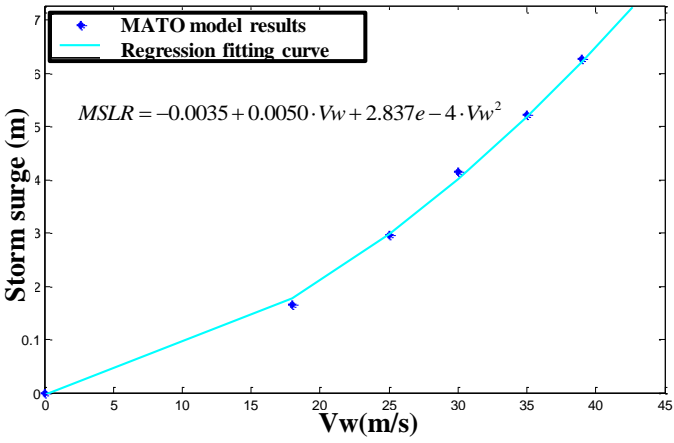

Figure 7. (a) Storm surge values as a function of the numerical simulation time, for wind coming from ENE.

(b) Storm surge as a function of the wind velocity, for wind coming from ENE.

The following sections show the parameters numerically obtained as sources of risk.

Wind and wave characterization
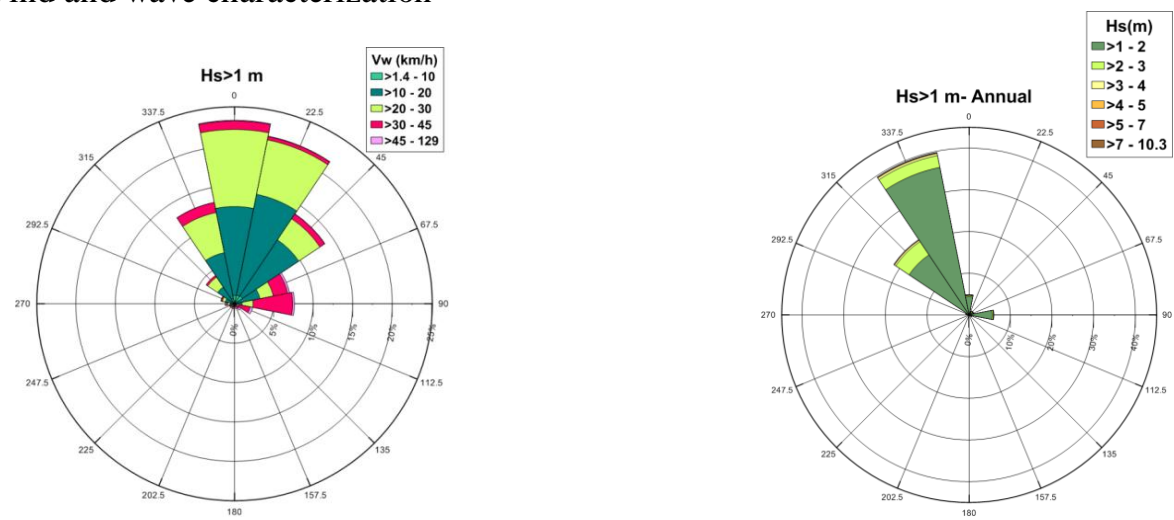

Figure 8. Annual wind and wave roses in storm conditions, on the left and right side respectively. 

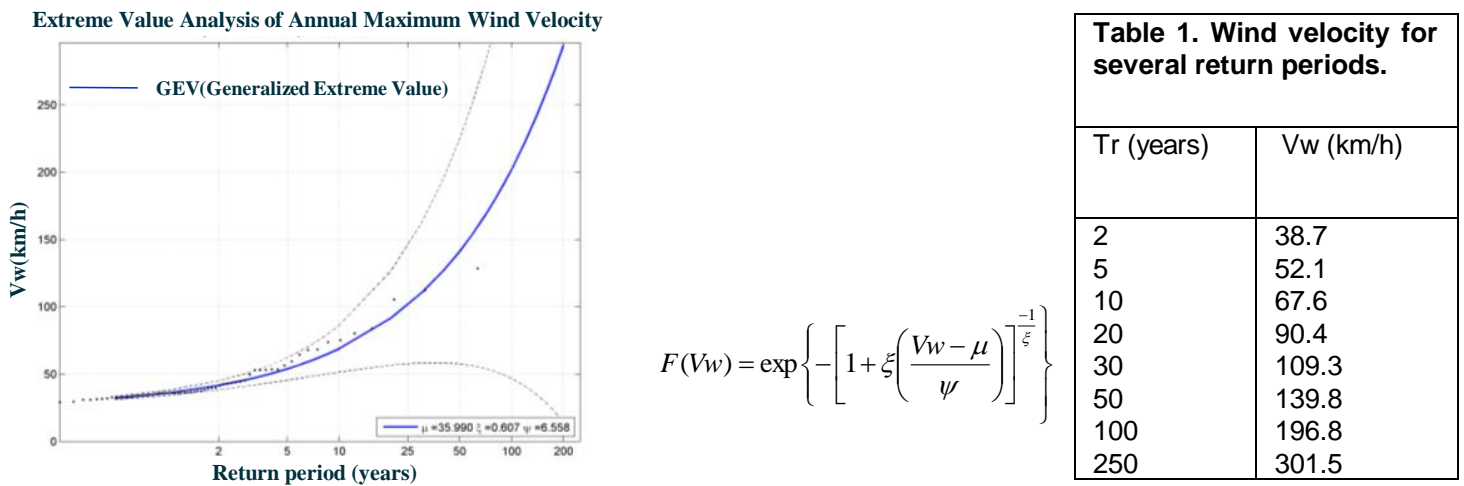

Figure 9. Extreme value analysis of wind velocity.
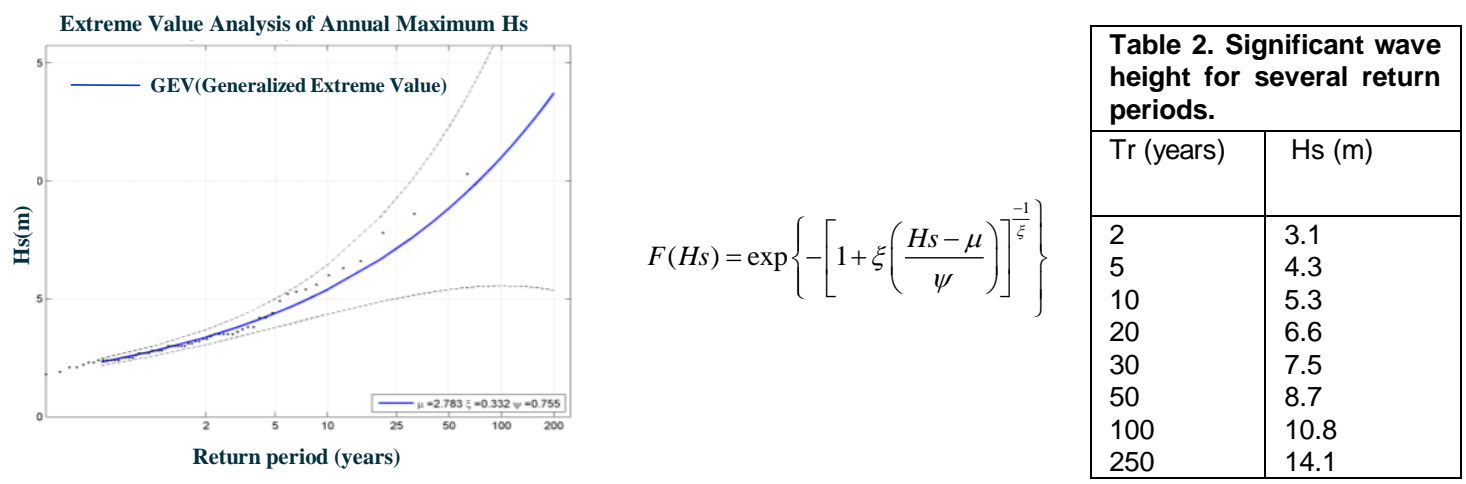

Figure 10. Extreme value analysis of significant wave height.

Figure 11 shows the joint probability between the significant wave height and peak period, on the left panel; and the mean duration of storm events, which are used for the selection of the simulation time in the XBeach numerical model application, on the right.

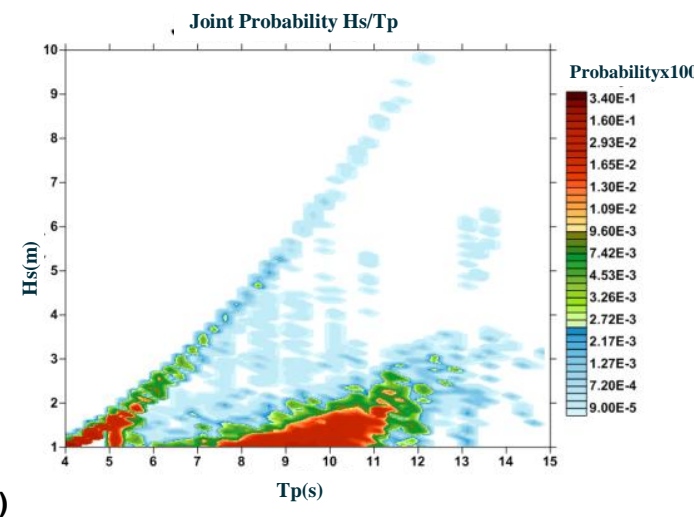

(b)

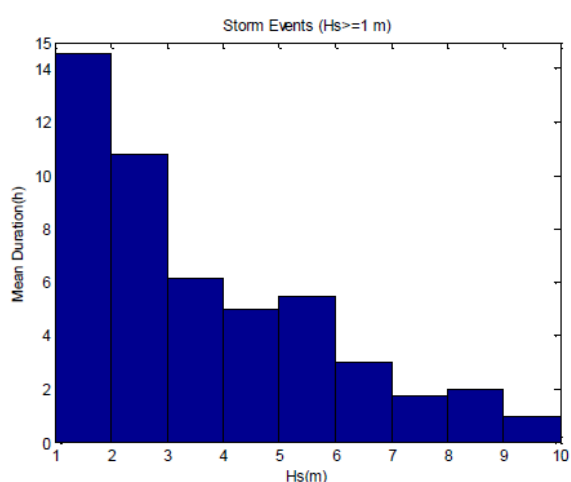

Figure 11. (a) Joint probability Hs/Tp of storm events.

(b) Mean duration of storm events.

Storm surge characterization

The mean sea level surge associated with each return period is estimated from the wind and wave results of extreme analysis and the wind roses of storm events, as shown in figure 12 for the storm events defined by a significant wave height between 4 and 5 meters. 


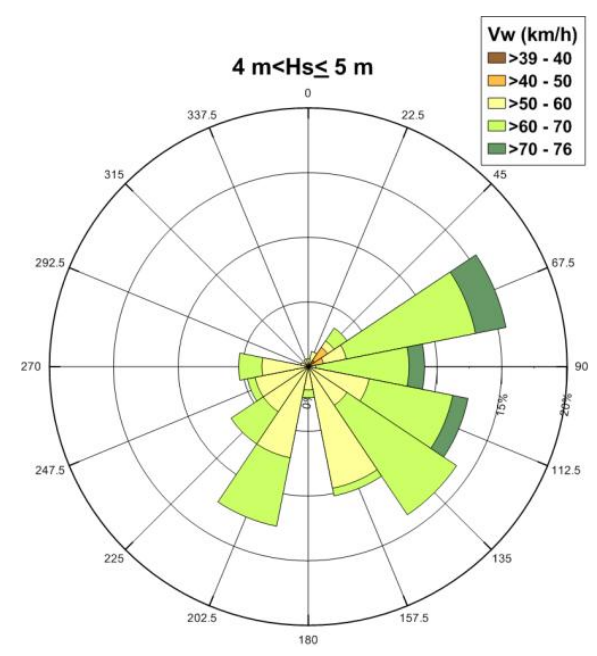

\begin{tabular}{|c|c|c|c|c|}
\hline $\begin{array}{l}\text { Tr } \\
\text { (years) }\end{array}$ & $\begin{array}{l}\mathrm{Vw} \\
(\mathrm{km} / \mathrm{h})\end{array}$ & $\mathrm{Hs}(\mathrm{m})$ & $\theta w$ & $\begin{array}{l}\text { Sea level } \\
\text { rise }(m)\end{array}$ \\
\hline 2 & 38.7 & 3.1 & $\begin{array}{c}\text { NNW } \\
\text { N } \\
\text { NW } \\
\text { NE }\end{array}$ & $\begin{array}{l}0.2 \\
0.3 \\
0.2 \\
0.3 \\
\end{array}$ \\
\hline 5 & 52.1 & 4.3 & $\begin{array}{c}\text { ENE } \\
\text { NE } \\
N\end{array}$ & $\begin{array}{l}0.2 \\
0.3 \\
0.4\end{array}$ \\
\hline 10 & 67.6 & 5.3 & $\mathrm{~N}$ & 0.6 \\
\hline 20 & 90.4 & 6.6 & $\begin{array}{c}\text { ENE } \\
\mathrm{N}\end{array}$ & $\begin{array}{l}0.4 \\
1.1\end{array}$ \\
\hline 30 & 109.3 & 7.5 & $\begin{array}{c}\text { ENE } \\
\mathrm{N}\end{array}$ & $\begin{array}{l}0.6 \\
1.5\end{array}$ \\
\hline 50 & 139.8 & 8.7 & $\begin{array}{c}\text { ENE } \\
\mathrm{N}\end{array}$ & $\begin{array}{l}0.9 \\
2.3\end{array}$ \\
\hline 100 & 196.8 & 10.8 & $\begin{array}{c}\text { ENE } \\
\mathrm{N}\end{array}$ & $\begin{array}{l}1.6 \\
4.4\end{array}$ \\
\hline 250 & 301.5 & 14.1 & $\mathrm{~N}$ & 9.9 \\
\hline
\end{tabular}

Figure 12. Mean sea level surge associated with several return periods.

The differences between the estimated values on the several cells are not significant because of the uniformity of topography in the area, of which the highest value is selected.

The results of the risk sources are expressed by the simulation scenarios are defined in the following table:

\begin{tabular}{|c|c|c|c|c|c|}
\hline $\operatorname{Tr}$ (years) & $\mathrm{Hs}(\mathrm{m})$ & $\mathrm{Tm}(\mathrm{s})$ & $\theta$ & $\begin{array}{l}\text { Storm } \\
\text { surge }(m)\end{array}$ & $\begin{array}{l}\text { Simulation } \\
\text { time (s) }\end{array}$ \\
\hline 2 & 3.1 & 6789 & $\begin{array}{c}\text { NNW } \\
\text { N } \\
\text { NW } \\
\text { NE }\end{array}$ & $\begin{array}{l}0.2 \\
0.3 \\
0.2 \\
0.3\end{array}$ & 21600 \\
\hline 5 & 4.3 & 67 & $\begin{array}{c}\text { ENE } \\
\text { NE } \\
N\end{array}$ & $\begin{array}{l}0.2 \\
0.3 \\
0.4\end{array}$ & 18000 \\
\hline 10 & 5.3 & 789 & $\mathrm{~N}$ & 0.6 & 19800 \\
\hline 20 & 6.6 & 67 & $\begin{array}{c}\text { ENE } \\
N\end{array}$ & $\begin{array}{l}0.5 \\
1.1\end{array}$ & 10800 \\
\hline 30 & 7.5 & 7 & $\begin{array}{c}\text { ENE } \\
\mathrm{N}\end{array}$ & $\begin{array}{l}0.6 \\
1.5\end{array}$ & 7200 \\
\hline 50 & 8.7 & 78 & $\begin{array}{c}\text { ENE } \\
\mathrm{N}\end{array}$ & $\begin{array}{l}0.9 \\
2.3\end{array}$ & 7200 \\
\hline 100 & 10.8 & 8 & $\begin{array}{c}\text { ENE } \\
\mathrm{N}\end{array}$ & $\begin{array}{l}1.6 \\
4.4 \\
\end{array}$ & 3600 \\
\hline 250 & 14.1 & 89 & $\mathrm{~N}$ & 9.9 & 3600 \\
\hline
\end{tabular}

The monochromatic wave considered is defined by $\mathrm{H}=\mathrm{Hs}$ and $\mathrm{T}=\mathrm{Tm}$ for the different wave directions. In future analysis, this study will be compared with spectral wave.

\section{Pathway}

The topography of the study site was obtained at high resolution along the aerial zone of the beach by means of sampling with GPS. Moreover, a 3D laser scan was used to measure topography in three relevant zones along the island, as shown figure 13. The rest of the island's topography was obtained from satellite database. 
(a)

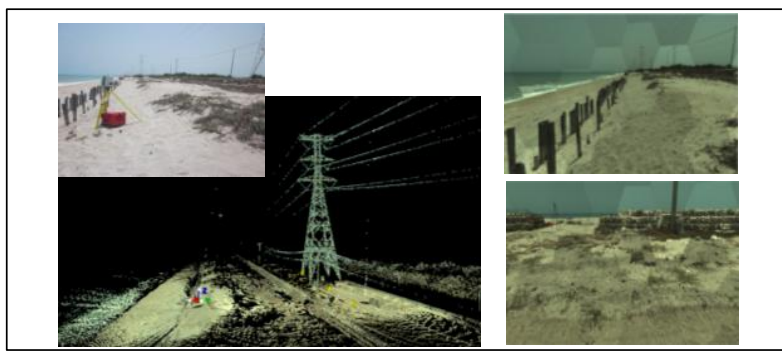

(b)

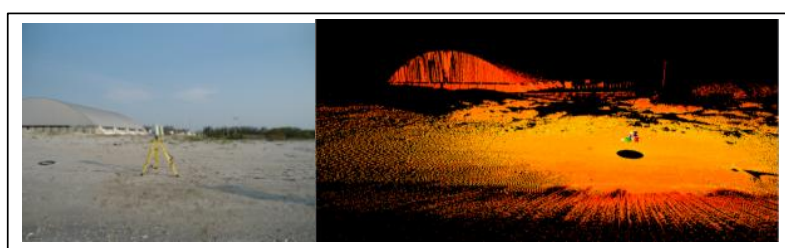

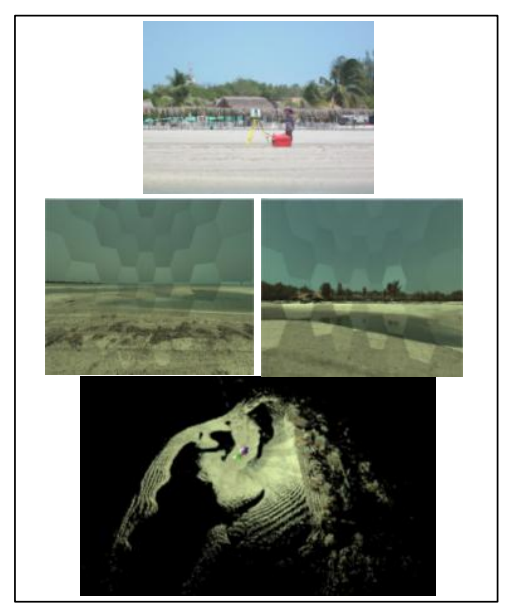

Figure 13. (a) Area close to the highway that crosses Isla del Carmen and mangrove zone.

(b) Area of low altitude surrounded by mangrove, where the turtles lay their eggs.

(c) Area close to Ciudad del Carmen.

In total, twelve grids were made along the study site for a suitable application of the numerical models in terms of computation time and grid orientation (Figure 14). Moreover, a third grid is included overlapping two consecutive grids to avoid possible numerical effects in the area close to the border of the grids.

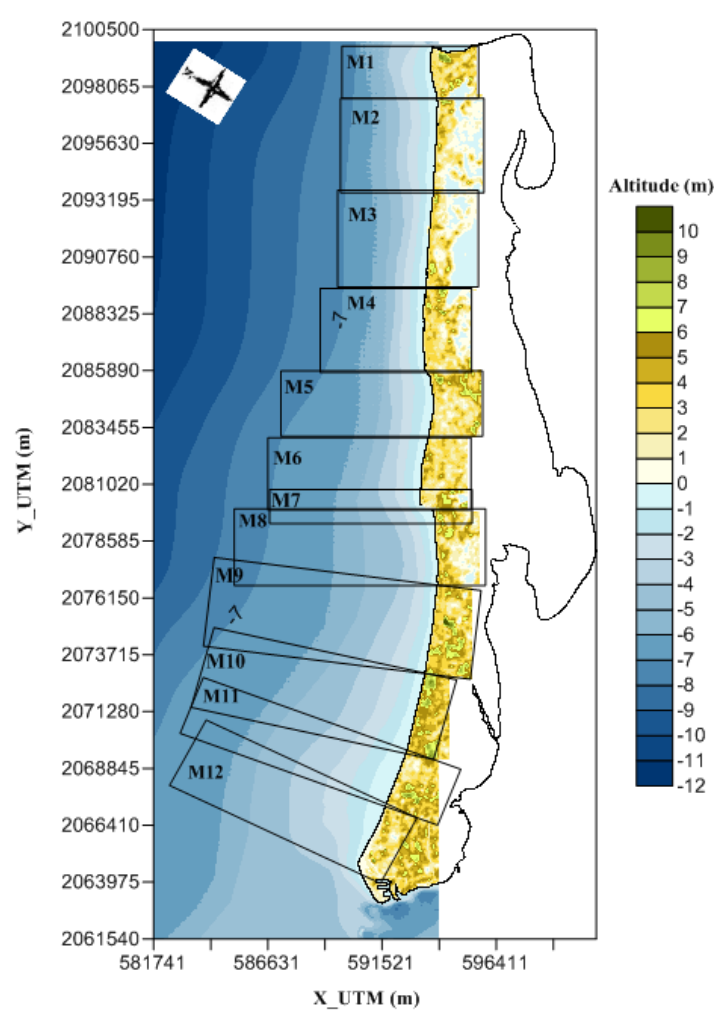

Figure 14. Sketch of the grid used in the application of the XBeach numerical model.

The grid size used is $25 \mathrm{~m}$ and $10 \mathrm{~m}$ for the Refdif and XBeach application, respectively. 

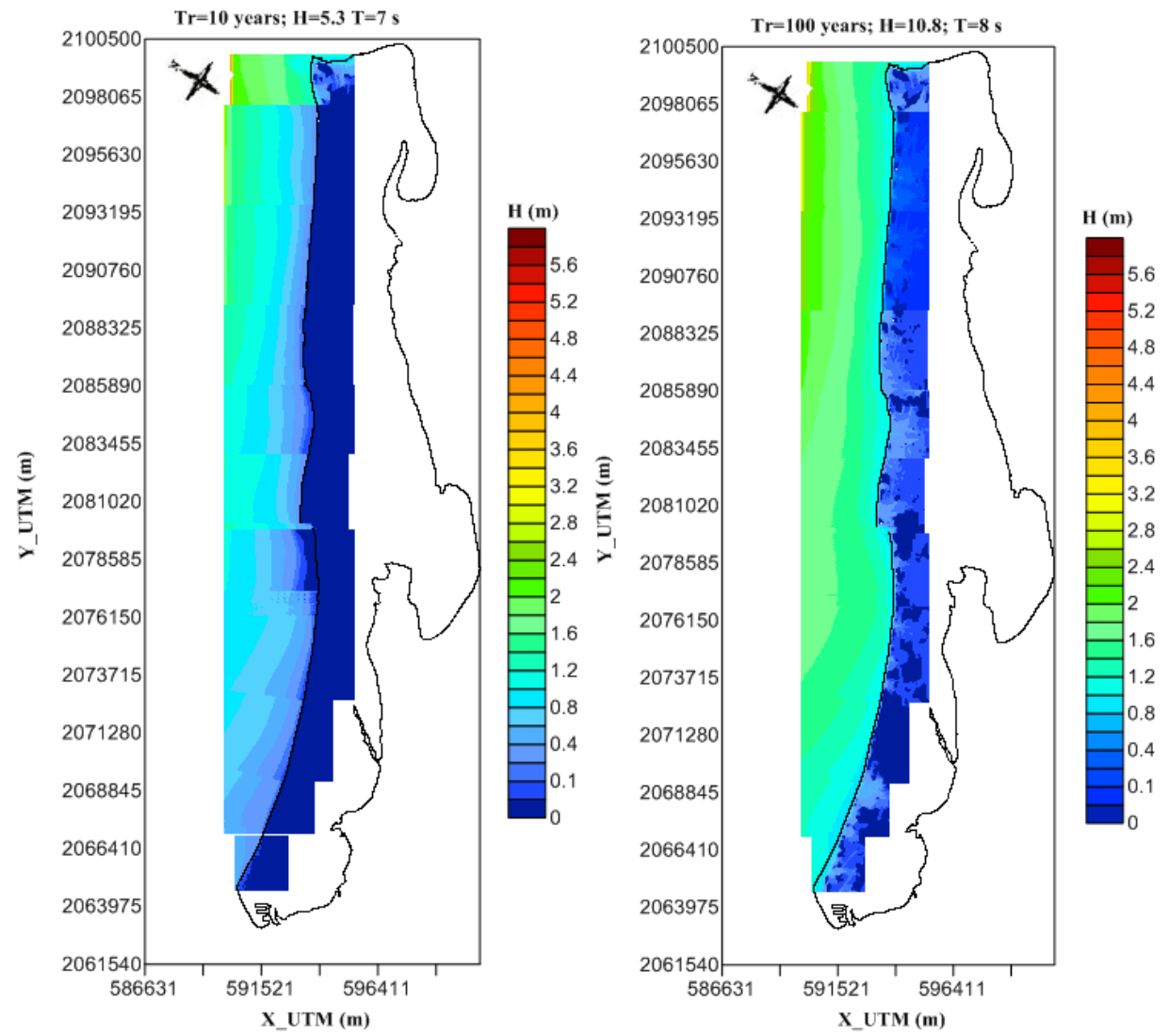

Figure 15. (a) Inundation depth associated with a $\mathrm{Tr}=10$ year, $\mathrm{H}=\mathrm{T}=7 \mathrm{~s}, \mathrm{~N}$.

(b) Inundation depth associated with a $\mathrm{Tr}=100$ year, $\mathrm{H}=\mathrm{T}=\mathbf{8} \mathrm{s}, \mathrm{N}$.

\section{Receptor}

Case 1

The expected damage to the dune is assessed in terms of changes (in percentage) in the Ecosystem services, based on the methodology proposed by Dassanayake et al 2010.

The parameters considered for the identification of the rate of degradation are erosion, flood depth and salt intrusion.

- Erosion: is calculated as the difference between the initial and final bed level, after the simulation of storm conditions. They are obtained from the XBeach numerical model application.

- Flood depth: is also obtained from the XBeach model.

- Salt intrusion: is calculated as the product between the inundation depth in each cell and the salinity of the Gulf of Mexico ( $0.035 \mathrm{~kg}$ of salt dissolved in $1 \mathrm{~kg}$ of sea water).

Finally, the value of change is defined as follows:

$$
\text { Ecos ystem_change }=a^{*} \text { Erosion }+b^{*} \text { Flood }+c^{*} \text { Salt }
$$

where Erosion, Flood and Salt are the erosion, flood depth and salt intrusion influence, respectively, on the degradation of the ecosystem; $a, b$ and $c$ are the weighting parameters of each parameter according to its importance.

The assigned weighting factors are:

$\mathrm{a}=$ erosion $=0.5$

$\mathrm{b}=$ flooding $=0.25$

$\mathrm{c}=$ salt intrusion $=0.25$

The values of erosion parameters and total change are defined to range from 0 to 1. 
The following figures show the results obtained in a stretch of the coastal zone 850 meters in length.
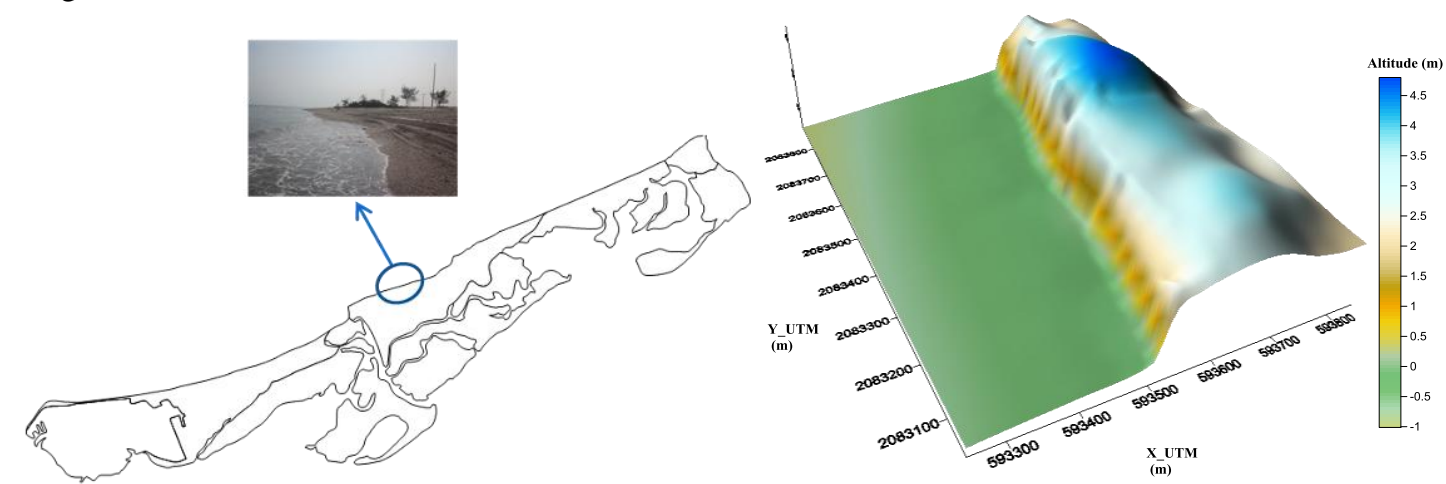

Figure 16. Stretch of the coastal zone used to show the damage assessment.
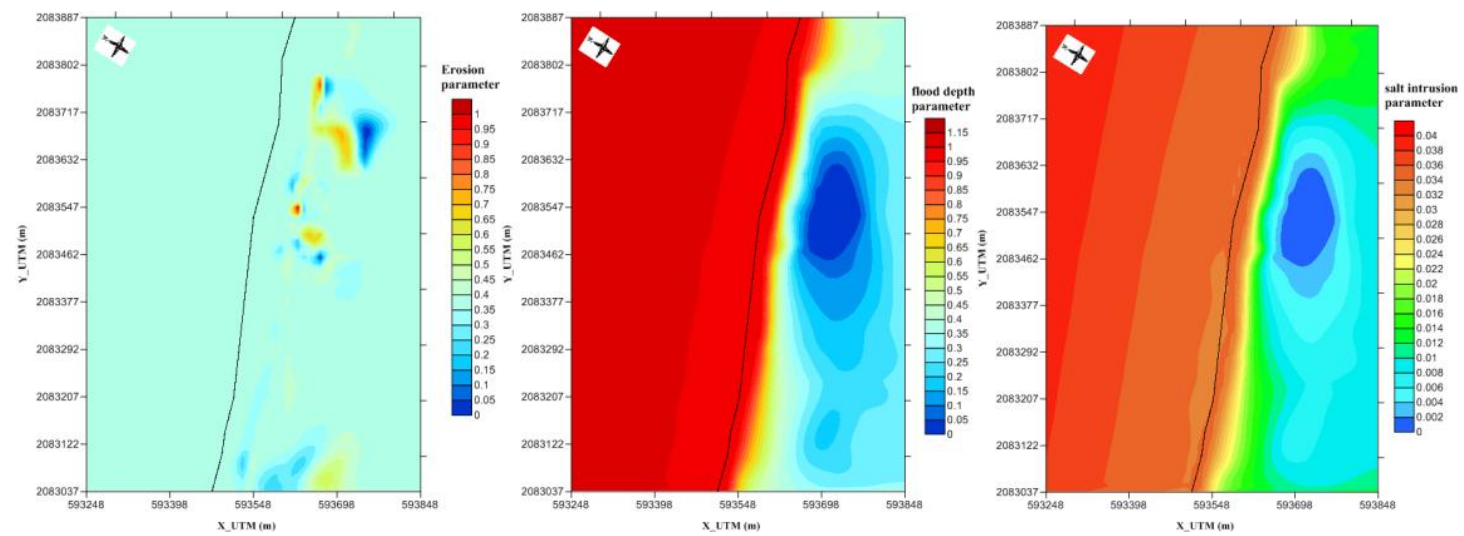

Figure 17. Distribution of the parameters considered to define the ecosystem changes ( $\mathrm{Tr}=100$ years; $\mathrm{H}=10.8 \mathrm{~m}$; $\mathbf{T}=\mathbf{8} \mathbf{s})$.

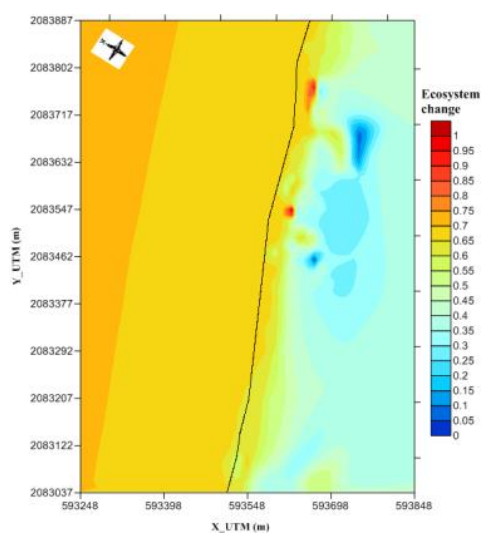

Figure 18. Ecosystem changes of the study area selected ( $T r=100$ years; $H=10.8 \mathrm{~m} ; T=8 \mathrm{~s}$ )

Case 2

In this case, the criteria selected to define the socio-economical and ecological damages are:

- Economic damage (monetary terms):

1. Building.

2. Private inventory.

3. Stock value.

4. Gross value added. 
- Social damage (number of people at risk):

1. Vulnerable groups.

2. Social hot spots.

3. Social structures.

- Ecological damage (size of each area):

1. Coastal biotopes (mangrove, pasture, forest).

2. Vulnerable groups.

3. Other threatened ecosystems (sea turtle).

The following figures show the spatial distribution of some of the parameters used to evaluate each criterion:
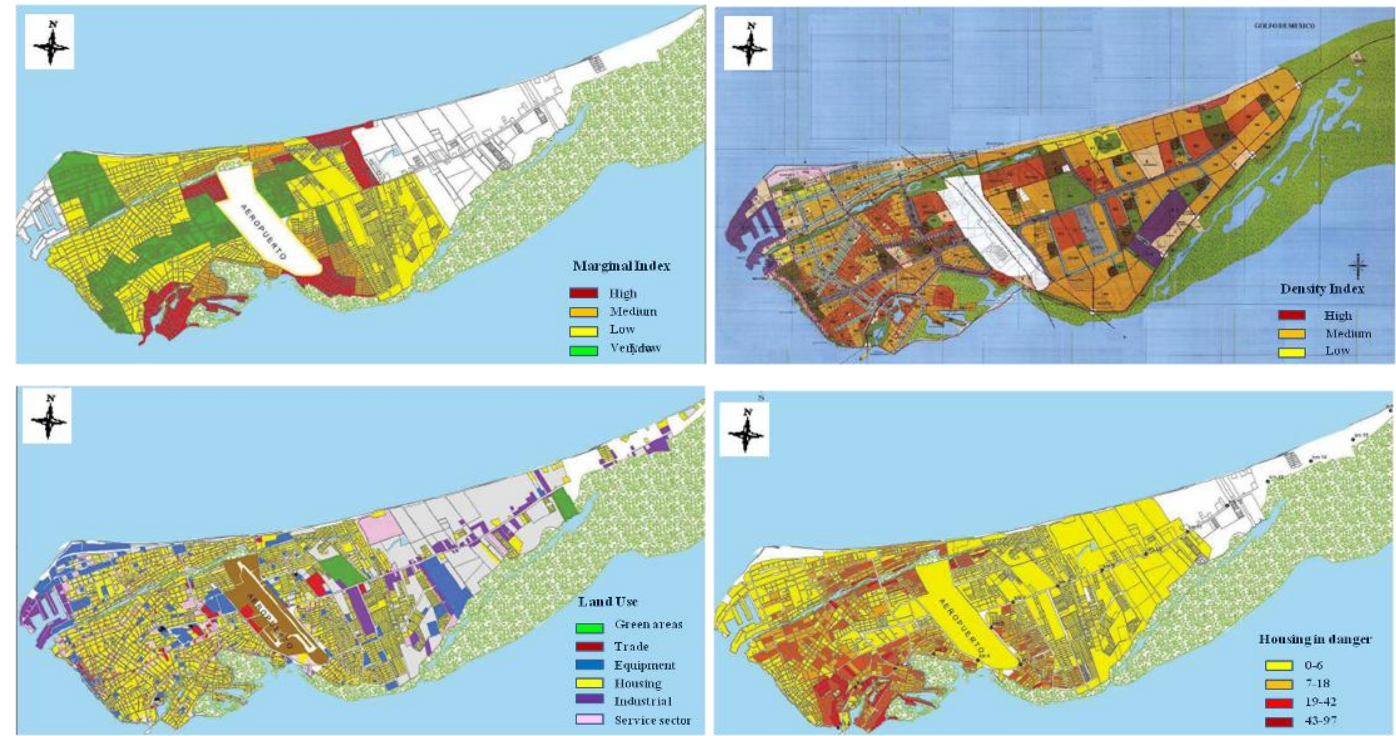

Figure 19. Parameters used to evaluate the socio-economical damages.

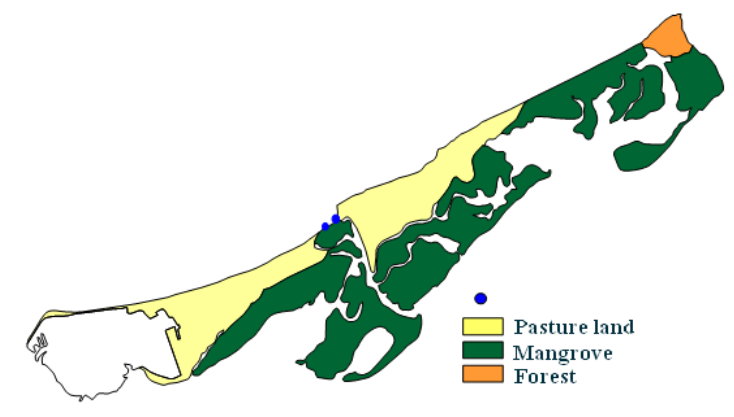

Figure 20. Parameters used to evaluate the ecological damages.

Figure 21 shows the inundation depth associated with the return periods of 10, 20, 50 and 100 years in the area defined by the grid M12, which covers part of Ciudad del Carmen. 

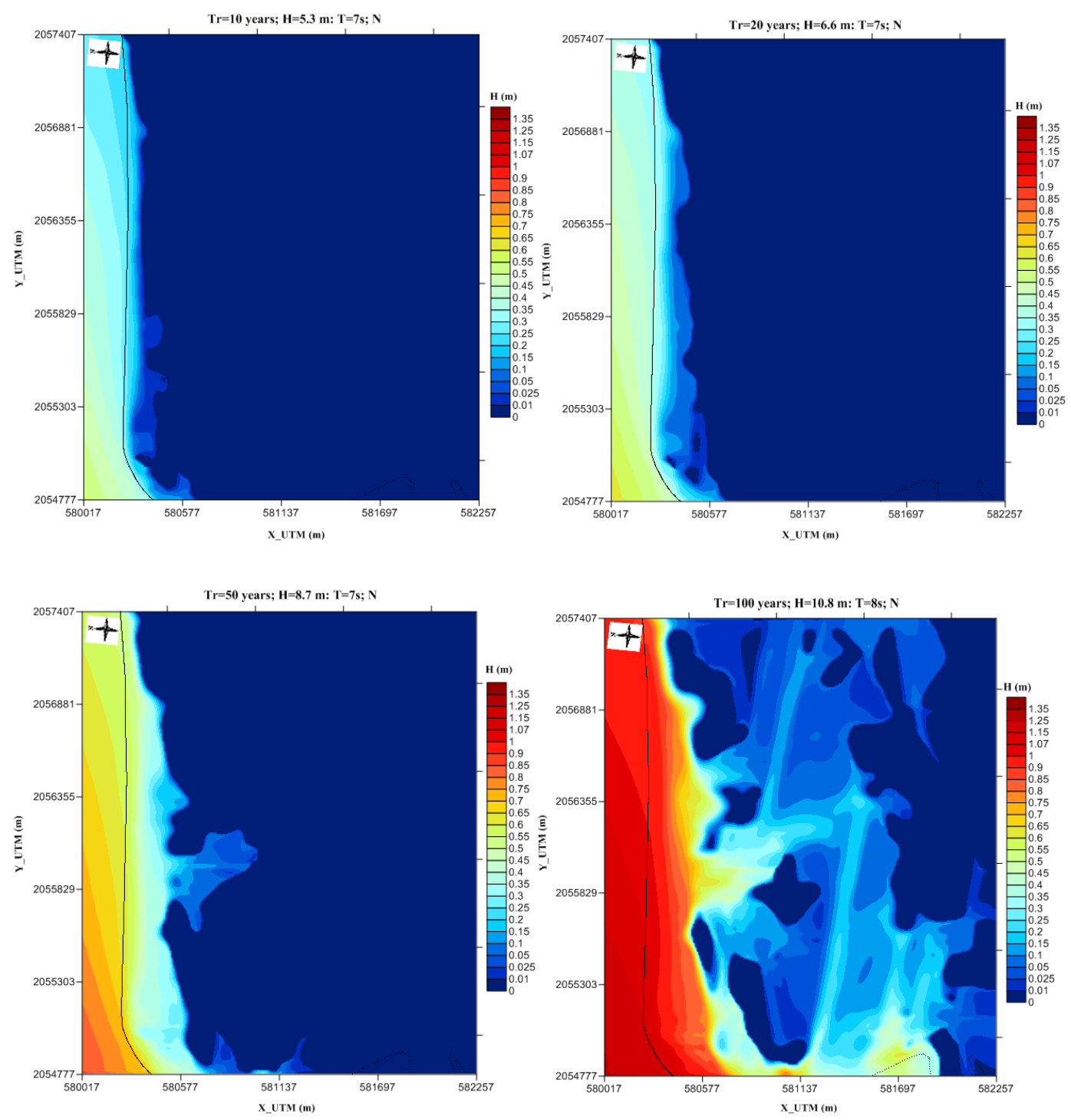

Figure 21. Inundation depth associated to $\mathrm{Tr}=10,20,50$ and 100 years, in grid $\mathrm{M} 12$. 

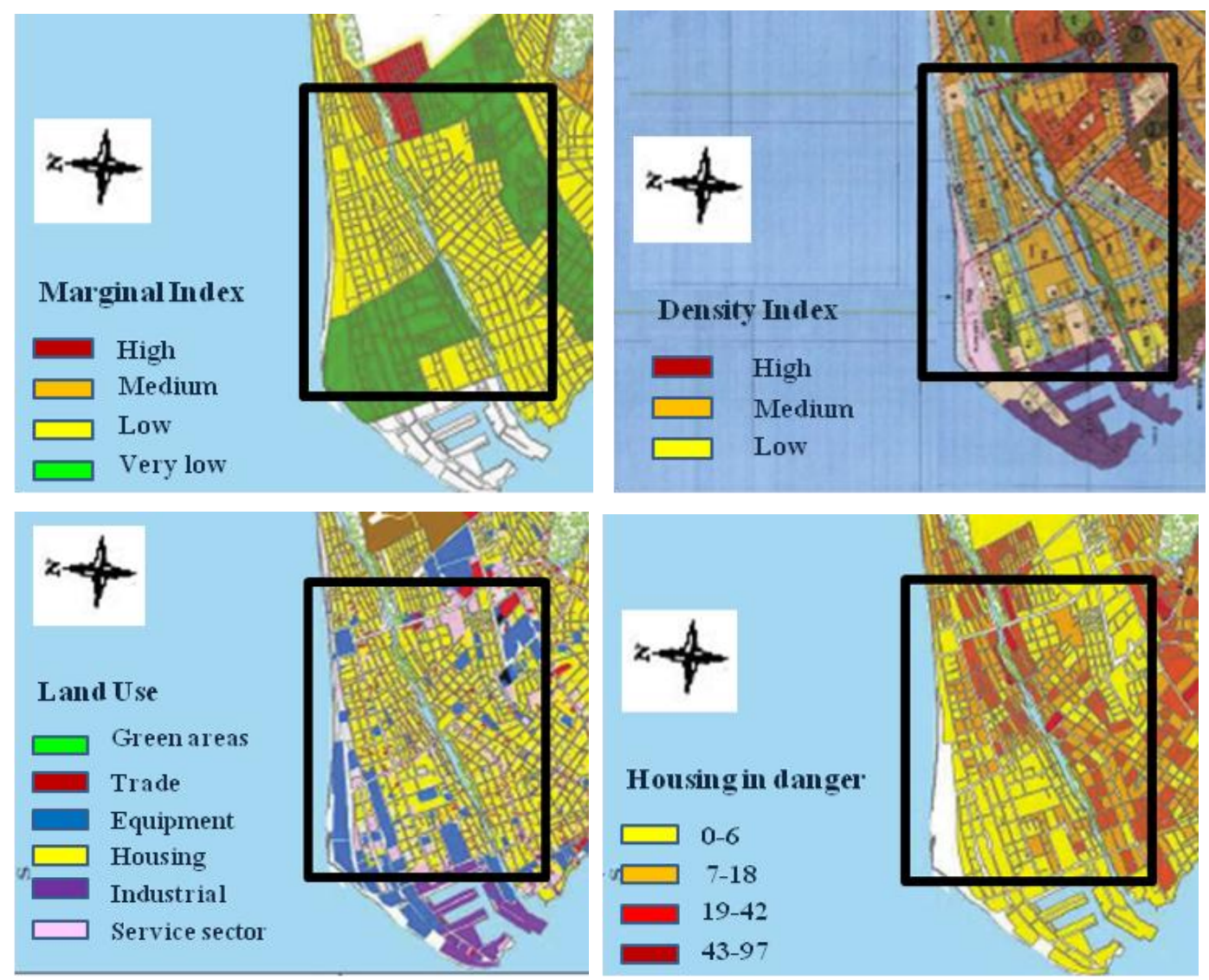

\section{Figure 22. Distribution of the parameters to evaluate the risk in grid M12.}

According to the maps of inundation depth, the highest inundation hazard is localized in areas with a medium density of population, where housing is the predominant land use. There is a considerable number of houses in danger situated in this area, which will be more susceptible to suffer damage and therefore a higher flooding risk.

The risk in areas with a higher marginality index will significantly increase for the most extreme wave conditions analyzed.

Analyzing the flooding risk as a function of the return period, it is important to highlight the increase of the flooding hazard in the zone close to the coast, above all in the central zone, with more extreme wave conditions. In this area, the location of sport, cultural, educational and recreative equipment leads to a higher socio-economic flooding risk.

\section{CONCLUSIONS}

In this paper, an application of the source-pathway-receptor model is presented to evaluate the flooding risk in an area annually affected by hurricane effects. The results are a first approximation of the flooding risk evaluation in Isla del Carmen, which will help in the taking of appropriate measures to reduce the damages caused by flooding.

Moreover, the analysis of the ecological risk on the coastal dune benefits the authorities in the drawing up of specific legislation to support its environmental protection.

Further studies in the area will include spectral wave analysis and risk indices definition.

\section{ACKNOWLEDGMENTS}

The support of the EU Collaborative Project Theseus; "Innovative technologies for safer European coasts in a changing climate", contract ENV.2009-1 No. 244104 is gratefully acknowledged. 


\section{REFERENCES}

Burzel, A., D. Dassanayake, M. Naulin, A. Kortenhaus, H. Oumerachi, T. Wahl et al. 2010. Integrated flood risk analysis for extreme storm surges (XTREMRISK), Proceedings of $32^{\text {th }}$ International Conference on Coastal Engineering (ICCE), Shanghai, China.

CONABIO. 2009. Manglares de México: Extensión y distribución. Comisión Nacional para el Conocimiento y Uso de la Biodiversidad, México.

Dassanayake, D.R., A. Burzel, A. Kortenhaus, and H. Oumeraci. 2010. Framework and methods for the evaluation of intangible losses and their integration in coastal flood risk analysis.

Durán G. 2010, Análisis del peligro por marea de tormenta en el Golfo de México, Tesis de maestría, UNAM, México.

Gouldby, B., and P. Samuels. 2005. Language of risk- Project definitions, FLOODsite EU Integrated Project, Research Report T32-04-01.

Jha, A., J. Lamond, R. Bloch, N. Bhattacharya, A. López, N. Papachristodoulou et al. 2011. Five Feet High and Rising- Cities and Flooding in the 21st Century, Policy Research Working Paper 5648.

Kirby J.T., and R.A. Dalrymple. 1994. Combined Refraction/Diffraction Model REF/DIF 1, Center for Applied Coastal Research, University of Delaware, Newark.

Marquez, A., V. Torres, A. Bolongaro, J. Chavarría, F. Varona, G. Expósito et al. 2008. Estudio de la dinámica costera del litoral norte del municipio del Carmen, Campeche, Universidad Autónoma del estado de Morelos.

Monbaliu, J., R. Padilla. 2000. The spectral wave model, WAM, adapted for applications with high spatial resolution, Coastal Engineering, 41, 41-62.

Narayan, S., S. Hanson, R.J. Nicholls, and D. Clarke. 2011. Use of the source-pathway-receptorconsequence model in coastal flood risk assessment, European Geosciences Union General Assembly, Vienna, Austria.

Oumeraci, H., J. Jensen, G. Gönnert, E. Pasche, A. Kortenhaus, M. Naulin, T. Wahl et al. 2009. Flood risk analysis for a megacity: The German XtremRisK project, Proc. Conference on Road Map towards a Flood Resilient Urban Environment, Paris.

Posada, G. 2007. Modelo numérico hidrodinámico tridimensional para la predicción de la evolución de una descarga de una substancia conservativa de un emisor submarino, Tesis doctoral, UNAM, México.

Roelvink D., A. Reniers, A. van Dongeren, J. van Thiel, J. Lescinski, and R. McCall. 2010. XBeach model description and manual, Unesco-IHE Institute for Water Education, Deltares and Delf University of Technology. 